\title{
Effect of low water temperature on metabolism and growth of a subtropical strain of Caulerpa taxifolia (Chlorophyta)
}

\author{
John R. M. Chisholm ${ }^{1, *}$, Manuel Marchioretti ${ }^{1}$, Jean M. Jaubert ${ }^{1,2}$ \\ ${ }^{1}$ Observatoire Océanologique Européen, Centre Scientifique de Monaco, Avenue Saint-Martin, 98000, Principality of Monaco \\ ${ }^{2}$ Université de Nice-Sophia Antipolis, Laboratoire d'Ecologie Expérimentale, Campus Valrose, 06108 Nice Cédex 02 , France
}

\begin{abstract}
The cold tolerance capacity of samples of the marine green alga Caulerpa taxifolia, obtained from Moreton Bay, Brisbane, Australia, was investigated by exposing samples to seawater temperatures of 9 to $15^{\circ} \mathrm{C}$, for periods of 4 to $10 \mathrm{wk}$, after maintenance at $22^{\circ} \mathrm{C}$. Residual effects of cold water exposure were evaluated by re-acclimating samples to $22^{\circ} \mathrm{C}$. Phenotypic expression and survivorship were monitored throughout both cold treatment and re-acclimation phases. Measurements of photosynthesis and respiration were made toward the end of the cold treatments and after re-acclimation. Samples exposed to 9 and $11^{\circ} \mathrm{C}$ water exhibited retraction or loss of chloroplasts (or chlorophyll) from the mid-rib regions of the pseudo-fronds. After $4 \mathrm{wk}$ of exposure to $9^{\circ} \mathrm{C}$ the only green coloured regions of the fronds were the extremities of the pinnules; 1 to $2 \mathrm{wk}$ later these samples began to decompose. Samples kept at $11^{\circ} \mathrm{C}$ retained the bulk of their photosynthetic pigments and survived throughout experiments. The stolons of samples tended to grow upward toward the seawater surface rather than parallel to the substratum. Samples at all treatment temperatures tended to become progressively detached from the substratum through stolon extension without intermittent rhizoid attachment. Several samples became fragmented and covered with mucilaginous epiphytes during re-acclimation, such that those lacking rhizoid anchorages, rose to the seawater surface, buoyed by metabolic gases trapped in the mucilage. During cold treatment, the maximal rates of gross and net photosynthesis $\left(P_{\mathrm{m}}^{\mathrm{g}}\right.$ and $\left.P_{\mathrm{m}}^{\mathrm{n}}\right)$, normalised to dry weight or tissue protein content, and the ratio of $P_{\mathrm{m}}^{\mathrm{g}}$ to dark respiration $(-R)$ varied directly with temperature. The irradiance required for compensation $\left(I_{\mathrm{c}}\right)$ varied inversely with temperature. The rate of dark respiration increased with cold exposure. Calculation of whole day net production indicated that rates of photosynthesis among samples incubated at $13^{\circ} \mathrm{C}$ or below were insufficient to maintain existing tissue biomass. There were no residual effects of cold exposure after re-acclimation, except that $11^{\circ} \mathrm{C}$ samples failed to increase in relative protein content as a function of ambient irradiance, perhaps due to nitrogen limitation. Results indicate a cold-tolerance threshold of 9 to $11^{\circ} \mathrm{C}$, thus genetic modification does not need to be invoked to explain the occurrence of $C$. taxifolia in the northwest Mediterranean.
\end{abstract}

KEY WORDS: Caulerpa taxifolia $\cdot$ Cold tolerance $\cdot$ Moreton Bay $\cdot$ Mediterranean

\section{INTRODUCTION}

Collectively, the green algal genus Caulerpa comprises species that exist for a proportion of each year in seawater that falls in temperature to below $12^{\circ} \mathrm{C}$ in winter or rises to above $25^{\circ} \mathrm{C}$ in summer (e.g. Taylor 1967, Sanderson \& Thomas 1987). At least one presumed tropical representative of the genus, C. taxifolia

*E-mail: j.chisholm@aims.gov.au
(Vahl) C. Agardh, is capable of withstanding this entire temperature range as demonstrated by its existence near the equator and in the northern Adriatic (e.g. Coppejans \& Prud'Homme van Reine 1992, Span \& Antolic 1994). It has been argued, however, that $C$. taxifolia is not naturally able to withstand northern Mediterranean winter seawater temperatures of 12 to $14^{\circ} \mathrm{C}$ and that wild populations do not grow in water cooler than $20^{\circ} \mathrm{C}$ (Meinesz et al. 1994, Caye et al. 1996, Meinesz \& Boudouresque 1996, Boudouresque 1997, 
Komatsu et al. 1997, Meinesz 1997). On this basis, it is claimed that the Mediterranean strain is not of natural origin and that it acquired enhanced cold tolerance through genetic modification or artificial selection while under culture in aquaria (Meinesz \& Hesse 1991, Meinesz et al. 1994, Caye et al. 1996, Meinesz \& Boudouresque 1996, Boudouresque 1997, Komatsu et al. 1997, Meinesz 1997, Jousson et al. 1998).

Until very recently, this hypothesis of exceptional, genetically based, cold tolerance appeared to have support among rDNA ITS sequence data. Jousson et al. (1998) demonstrated that Mediterranean populations have identical ITS sequences to a common aquarium variety of the species and that their ITS regions differ from those of Caribbean and Japanese strains. On these grounds, Jousson et al. (1998) claimed to have proven the aquarium origin of Mediterranean Caulerpa taxifolia. Recent studies of the allozyme composition (Benzie et al. 2000) and ITS sequences (Darius et al. 1999) of certain populations in the South Pacific, however, have not been able to distinguish between the Mediterranean variety and a strain existing on the east coast of Australia. Thus, debate as to whether or not the Mediterranean form of C. taxifolia has been genetically modified falls back on the argument of abnormal cold resistance.

It has been demonstrated that Mediterranean Caulerpa taxifolia can withstand a temperature of $10^{\circ} \mathrm{C}(\mathrm{Ko}-$ matsu et al. 1997) but this does not prove exceptional resistance because the cold tolerance capacity of nonMediterranean strains has not been tested. This is surprising given the existence of published records of the species in Bermuda (Taylor 1960), Mauritania (Feldman 1951), northern Senegal (Harper \& Garbary 1997), the Gulf of Suez (Lipkin 1973) and subtropical Australia (Cribb 1958), where sea temperatures fall below the proclaimed $20^{\circ} \mathrm{C}$ survival threshold (Meinesz et al. 1994, Caye et al. 1996, Meinesz \& Boudouresque 1996, Boudouresque 1997, Komatsu et al. 1997, Meinesz 1997).

In this study we examine the cold tolerance capacity of naturally occurring examples of Caulerpa taxifolia in an effort to determine if the Mediterranean strain exhibits abnormal resistance and thus could have an aberrant genetic constitution. To do this we collected samples from Moreton Bay, near Brisbane, Australia, subjected them to a range of low seawater temperatures and gathered information on survival potential and changes in metabolic activity (photosynthesis and respiration).

\section{MATERIALS AND METHODS}

Experimental samples. Sixty-six samples of Caulerpa taxifolia were obtained at a depth of 2 to $4 \mathrm{~m}$, near
One Mile Jetty, North Stradbroke Island, Moreton Bay, Australia $\left(153^{\circ} 22^{\prime}\right.$ E, $\left.27^{\circ} 27^{\prime} \mathrm{S}\right)$, in March 1997, by snorkeling. Samples were gathered from locations no closer than $5 \mathrm{~m}$ apart to minimise the chance of obtaining 2 or more samples from the same plant (maximum stolon length in the Mediterranean of $2.8 \mathrm{~m}$, see Meinesz et al. 1995). Samples were placed in clear plastic bottles containing fresh seawater and transported by air to Monaco in hand luggage; thus, samples were never exposed to temperatures below $20^{\circ} \mathrm{C}$.

Pre-treatment. Upon arrival in Monaco, the samples were distributed among 6 seawater aquaria (40 l). Each aquarium contained a $2.5 \mathrm{~cm}$ deep layer of coarse carbonate sand (2 to $4 \mathrm{~mm}$ grain diameter), enriched with organic matter (dead seagrass vegetation). The rhizoids were buried in the sediment by hand to provide temporary anchorage until the samples had naturally developed attachments to the substratum. Thereafter, samples were maintained at $22^{\circ} \mathrm{C}$, under $300 \mu \mathrm{mol}$ $\mathrm{m}^{-2} \mathrm{~s}^{-1}$ artificial light provided by high-power fluorescent strip lamps (Custom Sea Life, Carlsbad, CA, USA) operating on a 12:12 h light:dark cycle.

Low temperature treatments. In February 1999, 40 samples, each bearing 3 to 5 fronds, were gently uprooted and distributed evenly among 10 additional seawater aquaria (16 l) containing basal layers of coarse carbonate sand mixed with organic matter. Pairs of aquaria were placed inside 4 specially constructed thermoregulatory baths that were white in colour to maximise internal reflectance. One bath was fed directly with seawater pumped from a depth of $50 \mathrm{~m}$ in the northwest Mediterranean, and heated, initially, to $22^{\circ} \mathrm{C}$ using immersion elements. Thermoregulated freshwater was circulated through the other 3 baths using pumping temperature controllers (2 Polystat cc3, 1 Minichiller; Huber). The 2 remaining aquaria were surrounded with sheets of white polystyrene to provide insulation and equivalent reflectance and were fitted with immersion heaters. All aquaria were bubbled vigorously using air-stones throughout the course of experiments. Aquaria were kept in an unheated room with a translucent roof that admitted neutrally filtered sunlight $\left(116 \mu \mathrm{mol} \mathrm{m} \mathrm{m}^{-2} \mathrm{~s}^{-1}\right.$ initial irradiance adjacent to samples at noon). Fresh, pre-cooled seawater was added to each aquarium every 2 wk after removing the equivalent volume by siphoning ( $60 \%$ of tank volume).

Samples were kept at $22^{\circ} \mathrm{C}$ for $1 \mathrm{wk}$ prior to initiation of temperature treatments. Seawater temperature was then reduced by $1^{\circ} \mathrm{C}$ every $3.5 \mathrm{~d}$ in the 4 thermoregulatory baths until final temperatures of $14^{\circ} \mathrm{C}$ (ambient sea temperature at Monaco at the beginning of cold treatment), 13, 11 and $9^{\circ} \mathrm{C}$ were attained. Samples in the 2 remaining aquaria were maintained at $22^{\circ} \mathrm{C}$ to serve as controls. Temperature was measured daily 
between 09:00 and 10:00 h using a high precision mercury thermometer $\left(0.1^{\circ} \mathrm{C}\right.$ graduation). Additional, continuous recordings of temperature in each treatment were made over a number of days using a thermal data logger (Seamon mini) to determine the degree of temperature fluctuation. Seawater salinity was measured twice weekly using a portable salinometer (Conductivity Meter LF 196) that had been calibrated against standard seawater (IAPSO, Ocean Scientific International). Small volumes of freshwater were added as needed to compensate for evaporation. Samples were maintained for $4 \mathrm{wk}$ at $9^{\circ} \mathrm{C}, 6 \mathrm{wk}$ at $11^{\circ} \mathrm{C}, 8 \mathrm{wk}$ at $13^{\circ} \mathrm{C}$ and $10 \mathrm{wk}$ at ambient sea temperature $\left(14\right.$ to $\left.15^{\circ} \mathrm{C}\right)$. The pretreatment profile of temperature reduction was reversed at the end of each trial until samples had been brought back to the temperature of the controls.

Growth capacity. Toward the end of each cold treatment, measurements were made of photosynthesis and respiration. Replicate samples $(n=3)$ were detached from the substratum and adhering sediment was removed from the rhizoids. One day later, the samples were transferred to 3 acrylic incubation chambers (0.4 l volume), immersed side-by-side in a $40 \mathrm{l}$ glass tank, containing seawater held at the treatment temperature. The chambers were fitted with polarographic oxygen electrodes containing built-in temperature sensors (OXY-TS, Ponselle Mesure), basal stirring bars, plastic supporting grids for the algal samples and selfsealing inlet and outlet non-return valves. A small centrifugal pump was connected by Tygon tubing to each inlet valve to flush fresh seawater through the chambers at regular intervals (every $25 \mathrm{~min}$ ).

Oxygen sensors were calibrated before each set of measurements in a saturated solution of $\mathrm{Na}_{2} \mathrm{SO}_{3}$ (zero $\mathrm{O}_{2}$ ) and in air-saturated seawater. Outputs from the oxygen and temperature sensors were read every $4 \mathrm{~s}$ by a datalogger (Li-Cor Li-1000) and their mean values were stored in RAM at 1 min intervals. Illumination was provided by a metal-halide, discharge lamp (Philips HPIT $400 \mathrm{~W}$ ), mounted on rollers on a PVC track to enable irradiance to be controlled by varying the distance between the lamp and the subjects. An intervening screen of neutral density shade cloth was additionally used to provide samples with very weak irradiance. Irradiance was measured with a $4 \pi$ sensor (Li-Cor 193SA), placed adjacent to the incubation chambers. Irradiance was varied between 0 and $700 \mu \mathrm{mol} \mathrm{m} \mathrm{m}^{-2} \mathrm{~s}^{-1}$. Chambers were flushed with fresh seawater for $5 \mathrm{~min}$ at $0.51 \mathrm{~min}^{-1}$ before each set of measurements at a given irradiance.

After measurement of photosynthesis and respiration, algal samples were blotted dry and frozen at $-20^{\circ} \mathrm{C}$. Samples were freeze-dried, weighed and extracted twice into $90 \%$ acetone ( $24 \mathrm{~h}$ each) to remove chlorophylls $a$ and $b$ (chl $a$ and $b$ ) and once into $1 \mathrm{~N}$
$\mathrm{NaOH}\left(90^{\circ} \mathrm{C}\right.$ for $\left.30 \mathrm{~min}\right)$ to remove whole cell protein. Chlorophyll content was derived from spectrophotometric measurements of absorbance at 647 and $664 \mathrm{~nm}$ using the equations of Jeffrey \& Humphrey (1975). Total protein was quantified using the method of Bradford (1976).

Data analysis. Rates of oxygen production or consumption at each irradiance were calculated by regressing $\mathrm{O}_{2}$ concentration against time. Data acquired within $5 \mathrm{~min}$ of flushing were ignored to ensure that the sensors had stabilised. Rates of $\mathrm{O}_{2}$ flux were adjusted for chamber volume and plotted against irradiance. Light-saturation curves were constructed by fitting a simple exponential function:

$$
P=P_{\mathrm{m}}^{\mathrm{g}}\left(1-\mathrm{e}^{-I / I_{\mathrm{k}}}\right)+R \quad \text { (Webb et al. 1974) }
$$

to the data by the method of least squares (Igor Pro v.2.0.2., Wavemetrics, Inc.); $P$ is the rate of net photosynthesis; $P_{\mathrm{m}}^{\mathrm{g}}$ is the maximal rate of gross photosynthesis; $I$ is irradiance; $I_{\mathrm{k}}$ is the irradiance at which the initial slope $(\alpha)$ intercepts the horizontal asymptote at $I_{\mathrm{k}}$ and $R$ (which has negative sign) is the rate of dark respiration. Photosynthetic parameters were normalised to $\mathrm{chl} a$, total protein and dry weight.

Whole day net production was estimated by integrating the $P$ - $I$ equations with a peaked half sine curve approximation of daily irradiance (see Chisholm \& Jaubert 1997). The maximum amplitude of the peaked half sine curve was set at measured values of $130 \mu \mathrm{mol}$ $\mathrm{m}^{-2} \mathrm{~s}^{-1}$ during cold treatment and $186 \mu \mathrm{mol} \mathrm{m} \mathrm{m}^{-2} \mathrm{~s}^{-1}$ after re-acclimation to $22^{\circ} \mathrm{C}$. The measured value of $130 \mu \mathrm{mol} \mathrm{m} \mathrm{m}^{-2} \mathrm{~s}^{-1}$ was obtained at the beginning of the cold treatment, when seawater temperature near Monaco was close to minimum. Daylength during cold treatment was set at: (1) $680 \mathrm{~min}$ to approximate the daylight period in Monaco when the sea is at its coldest (February-March); and (2) $855 \mathrm{~min}$, the actual daylight period when measurements of productivity were made. Daylength after re-acclimation was set to that of 15 July.

\section{RESULTS}

Maximum irradiance adjacent to samples varied from $116 \mu \mathrm{mol} \mathrm{m} \mathrm{m}^{-2} \mathrm{~s}^{-1}$ at the beginning of experiments (i.e. before temperature adjustment) to $186 \mu \mathrm{mol} \mathrm{m} \mathrm{m}^{-2}$ $\mathrm{s}^{-1}$ at the end. Temperature was maintained at the target minima of 13,11 and $9^{\circ} \mathrm{C}$ to within $\pm 0.15^{\circ} \mathrm{C}$. Samples held at ambient temperature were exposed to a mean range of 14 to $15^{\circ} \mathrm{C}$ from beginning to end of the cold treatment and they experienced a greater degree of daily temperature fluctuation $\left( \pm 0.29^{\circ} \mathrm{C}\right)$. Salinity was maintained at $38.0 \pm 0.2 \mathrm{psu}$ throughout all treatments. 


\section{Effects on growth}

Cold treatment

During acclimation to reduced seawater temperature, samples exhibited stolon extension but little frond production. By the time temperatures of 13 to $14^{\circ} \mathrm{C}$ were reached, growth of the stolons had slowed appreciably and in most instances, samples ceased to form new rhizoid attachments to the substratum. Although there was almost no growth of stolons at 11 and $13^{\circ} \mathrm{C}$, samples produced a number of small frond initials. Samples held at $9^{\circ} \mathrm{C}$ exhibited progressive retraction or loss of chloroplasts (or chlorophyll) from the frond mid-ribs until, after $4 \mathrm{wk}$, the only distinctly green coloured regions were the pinnule apices and stolons (Fig. 1). Samples held at $11^{\circ} \mathrm{C}$ exhibited a less pronounced tendency toward 'bleaching' such that the mid-ribs of fronds retained a pale green colouration after $6 \mathrm{wk}$ of cold treatment (Fig. 1). Samples maintained above $11^{\circ} \mathrm{C}$ did not change substantially in colouration (Fig. 1). The tissues of samples tended to become stiff and brittle with increasing cold exposure. Occasionally, sections of stolon located between widely spaced rhizoid attachments to the substratum lost pigmentation and degenerated such that 2 separate samples were left where formerly there had been 1. Stolons in all cold treatments tended to grow upward toward the surface of the aquaria rather than parallel to the substratum, which is their normal mode of growth.
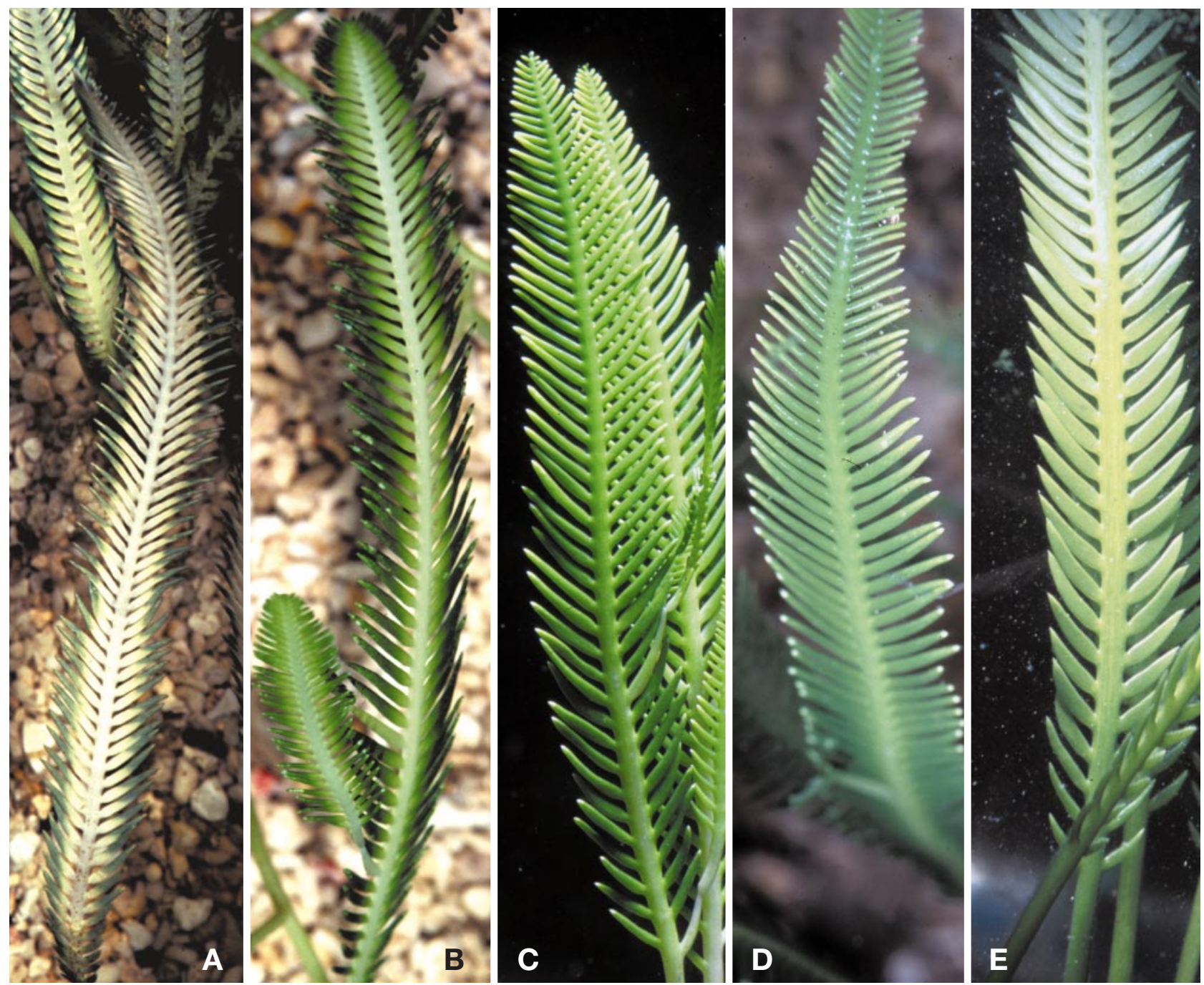

Fig. 1. Caulerpa taxifolia. Distribution of chlorophyll in the pseudo-fronds of cold treated samples after (A) 4 wk exposure to $9^{\circ} \mathrm{C}$, (B) $5 \mathrm{wk}$ exposure to $11^{\circ} \mathrm{C}$, (C) $6 \mathrm{wk}$ exposure to $13^{\circ} \mathrm{C}$ and (D) $7 \mathrm{wk}$ exposure to 14 to $14.6^{\circ} \mathrm{C}$ water compared with (E) the distribution of chlorophyll in the pseudo-fronds of control samples maintained at $22^{\circ} \mathrm{C}$. Samples held at $11^{\circ} \mathrm{C}$ or above maintained the intensity and distribution of chlorophyll shown in the figure for the remainder of the temperature treatment 
Table 1. Caulerpa taxifolia. Mean estimates and $95 \%$ confidence limits (in parentheses) of biochemical properties and $P$ - $I$ curve parameters of samples after: (1) exposure to the indicated cold treatment temperatures (upper section); and (2) following reacclimation to $22^{\circ} \mathrm{C}$ (lower section)

\begin{tabular}{|c|c|c|c|c|c|c|c|}
\hline $\begin{array}{l}\text { Temp } \\
\left({ }^{\circ} \mathrm{C}\right)\end{array}$ & $\begin{array}{c}\text { Chl a } \\
\left(\mathrm{mg} \mathrm{g} \mathrm{dw}^{-1}\right)\end{array}$ & $\begin{array}{c}\text { Protein } \\
\left(\mathrm{mg} \mathrm{g} \mathrm{dw}^{-1}\right)\end{array}$ & $\begin{array}{c}P_{\mathrm{m}}^{\mathrm{n}} \\
\left(\mu \mathrm{mol} \mathrm{O}_{2} \mathrm{~g}\right. \\
\left.\mathrm{dw}^{-1} \mathrm{~min}^{-1}\right)\end{array}$ & $\begin{array}{c}\alpha \\
\left(\mu \mathrm{mol} \mathrm{O} \mathrm{g} \mathrm{dw}^{-1} \mathrm{~min}^{-1}\right. \\
\left.\left[\mu \mathrm{mol} \mathrm{m} \mathrm{m}^{-2} \mathrm{~s}^{-1}\right]^{-1}\right)\end{array}$ & $\begin{array}{c}I_{\mathrm{C}} \\
(\mu \mathrm{mol} \\
\left.\mathrm{m}^{-2} \mathrm{~s}^{-1}\right)\end{array}$ & $\begin{array}{c}I_{\mathrm{k}} \\
(\mu \mathrm{mol} \\
\left.\mathrm{m}^{-2} \mathrm{~s}^{-1}\right)\end{array}$ & $\begin{array}{c}R \\
\left(\mu \mathrm{mol} \mathrm{O} \mathrm{O}_{2} \mathrm{~g}\right. \\
\left.\mathrm{dw}^{-1} \mathrm{~min}^{-1}\right)\end{array}$ \\
\hline 9 & $0.669( \pm 0.246)$ & $7.963( \pm 0.157)$ & $0.298( \pm 0.153)$ & $0.035( \pm 0.030)$ & $82.0( \pm 55.3)$ & $51.9( \pm 8.5)$ & $-1.476( \pm 1.495)$ \\
\hline 11 & $1.478( \pm 0.351)$ & $4.989( \pm 0.616)$ & $0.414( \pm 0.276)$ & $0.034( \pm 0.005)$ & $32.7( \pm 5.5)$ & $31.4( \pm 5.8)$ & $-0.662( \pm 0.084)$ \\
\hline 13 & $1.295( \pm 0.137)$ & $5.376( \pm 0.294)$ & $0.606( \pm 0.001)$ & $0.039( \pm 0.021)$ & $16.3( \pm 3.9)$ & $27.9( \pm 5.9)$ & $-0.478( \pm 0.320)$ \\
\hline 15 & $1.732( \pm 0.116)$ & $5.616( \pm 0.667)$ & $1.203( \pm 0.455)$ & $0.042( \pm 0.025)$ & $9.3( \pm 6.6)$ & $40.6( \pm 15.9)$ & $-0.278( \pm 0.107)$ \\
\hline 22 & $2.136( \pm 0.336)$ & $5.814( \pm 1.294)$ & $1.548( \pm 0.160)$ & $0.044( \pm 0.013)$ & $6.4( \pm 2.3)$ & $43.7( \pm 8.6)$ & $-0.270( \pm 0.164)$ \\
\hline $11 \rightarrow 22$ & $2.181( \pm 0.187)$ & $4.888( \pm 1.499)$ & $2.356( \pm 1.113)$ & $0.030( \pm 0.021)$ & $31.7( \pm 16.7)$ & $115( \pm 40.7)$ & $-0.619( \pm 0.118)$ \\
\hline $13 \rightarrow 22$ & $2.363( \pm 0.313)$ & $7.378( \pm 0.127)$ & $2.817( \pm 0.434)$ & $0.041( \pm 0.002)$ & $12.0( \pm 1.0)$ & $80.5( \pm 12.2)$ & $-0.455( \pm 0.015)$ \\
\hline $15 \rightarrow 22$ & $1.870( \pm 0.480)$ & $7.511( \pm 1.602)$ & $2.792( \pm 0.876)$ & $0.050( \pm 0.022)$ & $23.8( \pm 0.8)$ & $78.6( \pm 12.9)$ & $-1.019( \pm 0.411)$ \\
\hline $22 \leftrightarrow 22$ & $3.126( \pm 1.315)$ & $8.524( \pm 2.906)$ & $2.577( \pm 0.412)$ & $0.047( \pm 0.012)$ & $9.2( \pm 0.6)$ & $66.0( \pm 15.5)$ & $-0.397( \pm 0.082)$ \\
\hline
\end{tabular}

\section{Re-acclimation to $22^{\circ} \mathrm{C}$}

During re-acclimation to warmer seawater temperatures, samples that had been incubated at $9^{\circ} \mathrm{C}$ lost all of their remaining green colouration, became covered with epiphytes and died. Approximately half of the samples that had been incubated at $13^{\circ} \mathrm{C}$ and a third of the samples that had been incubated at $11^{\circ} \mathrm{C}$ broke apart into smaller fragments. Samples that had been incubated at $11^{\circ} \mathrm{C}$ or higher produced new fronds but were slow to form new rhizoid attachments to the substratum. This appeared to be largely due to a combination of the unattached extremities of the stolons having become elevated several centimeters above the substratum and later covered with mucilaginous algae, which trapped metabolic gases, buoying the stolon apices near the water surface. This mucilaginous algal cover also caused fragmented samples, lacking points of anchorage, to rise up from the substratum and float freely in the aquaria.

By the conclusion of experiments, all samples that had been maintained in water warmer than $9^{\circ} \mathrm{C}$ were alive, demonstrating a lethal temperature threshold of between 9 and $11^{\circ} \mathrm{C}$ over periods of 4 to $6 \mathrm{wk}$, for Moreton Bay samples of Caulerpa taxifolia.

\section{Effects on metabolism}

\section{During cold treatment}

Samples held at $9^{\circ} \mathrm{C}$ were barely capable of respiratory compensation at the irradiance available to them during cold treatment (ca $130 \mu \mathrm{mol} \mathrm{m} \mathrm{m}^{-2} \mathrm{~s}^{-1}$ ). Samples held at or above $11^{\circ} \mathrm{C}$ exhibited sufficient photosynthesis at $38 \mu \mathrm{mol} \mathrm{m} \mathrm{m}^{-2} \mathrm{~s}^{-1}$ to more than compensate for respiratory consumption (Table 1). Intriguingly, ca $50 \%$ of samples exposed to 11 and $13^{\circ} \mathrm{C}$ water ex- hibited significantly higher rates of photosynthesis at very low irradiance ( 0 to $30 \mu \mathrm{mol} \mathrm{m} \mathrm{m}^{-2} \mathrm{~s}^{-1}$ ) than could have been predicted from measurements made at higher irradiance. Although these data points needed to be ignored during curve fitting to obtain a satisfactory fit to the rest of the data, they indicate that compensation was attained at an irradiance of $<10 \mu \mathrm{mol}$ $\mathrm{m}^{-2} \mathrm{~s}^{-1}$ (Fig. 2). The compensation irradiance $\left(I_{\mathrm{c}}\right)$ varied inversely with culture temperature (Table 2) and could be described by an inverse hyperbolic tangent function (Fig. 3A), reflecting a decline in $P_{\mathrm{m}}^{\mathrm{g}}$ (g dry weight $\left.[\mathrm{dw}]^{-1}\right)$ and a rise in $-R\left(\mathrm{~g} \mathrm{dw}^{-1}\right)$ with falling temperature (Table 2).

Onset of light saturation $\left(I_{\mathrm{k}}\right)$ occurred between 28 and $52 \mu \mathrm{mol} \mathrm{m} \mathrm{m}^{-2} \mathrm{~s}^{-1}$ among samples incubated between 9 and $15^{\circ} \mathrm{C}$ (Table 1). The mean net photosynthetic capacities $\left(P_{\mathrm{m}}^{\mathrm{n}}\right)$ of samples ranged from $0.298 \mu \mathrm{mol}$ $\mathrm{O}_{2} \mathrm{~g} \mathrm{dw}^{-1} \mathrm{~min}^{-1}$ at $9^{\circ} \mathrm{C}$ to $1.548 \mu \mathrm{mol} \mathrm{O} \mathrm{g} \mathrm{dw}^{-1} \mathrm{~min}^{-1}$ at

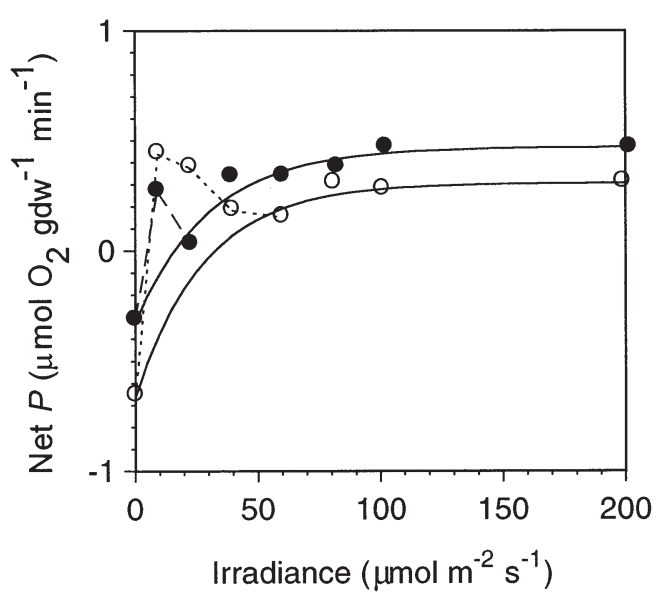

Fig. 2. Caulerpa taxifolia. Greater than expected initial rates of photosynthesis at very low irradiance $\left(<30 \mu \mathrm{mol} \mathrm{m}^{-2} \mathrm{~s}^{-1}\right)$ by samples at $11^{\circ} \mathrm{C}(\mathrm{o})$ and $13^{\circ} \mathrm{C}(\bullet)$ in relation to measurements made at higher irradiance 
Table 2. Caulerpa taxifolia. Linear relationships between temperature $(T)$ and photokinetic and respiratory parameters $(Y)$ of samples exposed to cold treatment, $r^{2}$ is the coefficient of determination, $\mathrm{p}$ is the probability that the regression slope is not significantly different from 0 ; ns: not significant

\begin{tabular}{|c|c|c|c|c|}
\hline$Y$ & Units & $Y=$ & $r^{2}$ & $\mathrm{p}$ \\
\hline$P_{\mathrm{m}}^{\mathrm{g}}$ & $\mu \mathrm{mol} \mathrm{O} \mathrm{g} \mathrm{dw}^{-1} \mathrm{~min}^{-1}$ & $0.281+0.071 T$ & 0.48 & 0.0091 \\
\hline$P_{\mathrm{m}}^{\mathrm{g}}$ & $\mu \mathrm{mol} \mathrm{O} \mathrm{O}_{2} \mathrm{chl} a^{-1} \mathrm{~min}^{-1}$ & & & ns \\
\hline$P_{\mathrm{m}}^{\mathrm{g}}$ & $\mu \mathrm{mol} \mathrm{O} \mathrm{O}_{2} \mathrm{mg}$ protein ${ }^{-1} \mathrm{~min}^{-1}$ & $0.045+0.013 T$ & 0.36 & 0.0289 \\
\hline$P_{\mathrm{m}}^{\mathrm{n}}$ & $\mu \mathrm{mol} \mathrm{O} \mathrm{g} \mathrm{dw}^{-1} \mathrm{~min}^{-1}$ & $0.100 T-0.593$ & 0.70 & 0.0004 \\
\hline$P_{\mathrm{m}}^{\mathrm{n}}$ & $\mu \mathrm{mol} \mathrm{O} \mathrm{O}_{2} \mathrm{chl} a^{-1} \min ^{-1}$ & & & ns \\
\hline$P_{\mathrm{m}}^{\mathrm{n}}$ & $\mu \mathrm{mol} \mathrm{O} \mathrm{O}_{2} \mathrm{mg}$ protein ${ }^{-1} \mathrm{~min}^{-1}$ & $0.018 T-0.103$ & 0.63 & 0.0012 \\
\hline$I_{\mathrm{c}}$ & $\mu \mathrm{mol} \mathrm{m} \mathrm{m}^{-2} \mathrm{~s}^{-1}$ & $62.0-2.802 T$ & 0.63 & 0.0012 \\
\hline$I_{\mathrm{k}}$ & $\mu \mathrm{mol} \mathrm{m} \mathrm{m}^{-2} \mathrm{~s}^{-1}$ & & & ns \\
\hline$-R$ & $\mu \mathrm{mol} \mathrm{O} \mathrm{g} \mathrm{dw}^{-1} \mathrm{~min}^{-1}$ & $0.029-0.874 T$ & 0.35 & 0.0342 \\
\hline$-R$ & $\mu \mathrm{mol} \mathrm{O} \mathrm{mg}_{2}$ protein $^{-1} \mathrm{~min}^{-1}$ & & & ns \\
\hline$P_{\mathrm{m}}^{\mathrm{g}} /-R$ & No units & $0.577 T-4.187$ & 0.68 & 0.005 \\
\hline
\end{tabular}

the control temperature of $22^{\circ} \mathrm{C}$ (Table 1) and varied directly with temperature (Fig. 3B), as did $P_{\mathrm{m}}^{\mathrm{g}} /-R$ (Table 2).

Estimated net $24 \mathrm{~h}$ production varied non-linearly with temperature. An excellent description of the data was provided by the hyperbolic tangent function. Fitted curves indicated that tissue biomass could have been maintained by photosynthesis at a temperature of $13.5^{\circ} \mathrm{C}$ given $680 \mathrm{~min}$ of daylight or at $10.9^{\circ} \mathrm{C}$ given a photoperiod of 855 min (Fig. 4).

Sample productivity was less variable within treatment groups when normalised to tissue dry weight than whole cell protein or chl a. $P_{\mathrm{m}}^{\mathrm{g}}$ and $P_{\mathrm{m}}^{\mathrm{n}}$ increased linearly with temperature when normalised by dry weight and protein content but
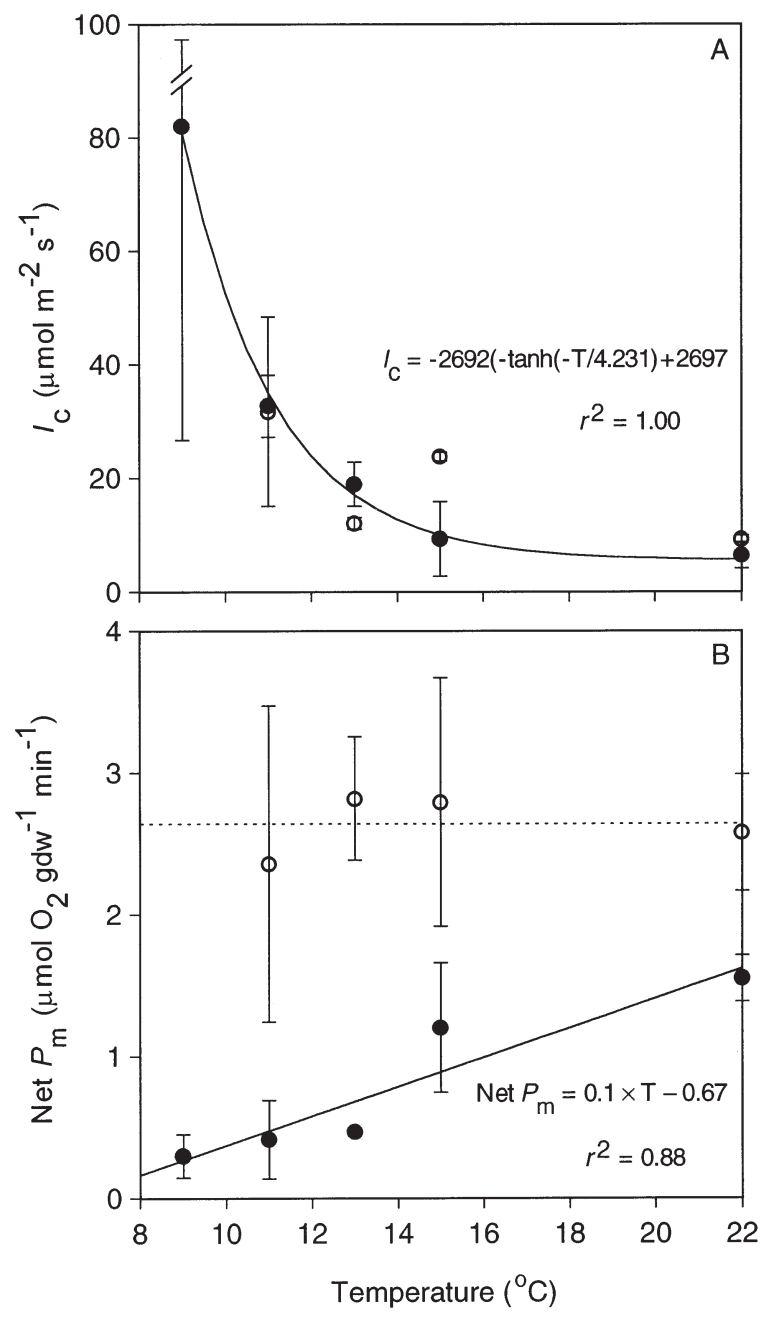

Fig. 3. Caulerpa taxifolia. Variation in (A) $I_{\mathrm{c}}$ and (B) $P_{\mathrm{m}}^{\mathrm{n}}$ of samples as a function of treatment temperature, during exposure to cold water $(\bullet)$ and after re-acclimation to $22^{\circ} \mathrm{C}$. (o) Error bars are $95 \%$ confidence intervals; dashed line in (B) is the mean of all samples not by chl a (Table 2 ). $-R$ decreased linearly with temperature when normalised to dry weight but not when normalised to protein (Table 2).

The tissue concentrations of chl $a$ and $b$ decreased linearly with cold exposure (Fig. 5A,B). The chl $a / b$ ratios and protein contents of samples incubated at $9^{\circ} \mathrm{C}$ differed significantly from those of all other samples (Tukey-Kramer HSD means comparison at $\alpha=0.05$ ): chl $a / b$ was lower (Fig. 5C); relative tissue protein content was higher (Fig. 5D). Removal of these data yielded an inversely proportionate relationship between chl $a / b$ and treatment temperature (Fig. 5C) and a directly proportionate relationship between protein

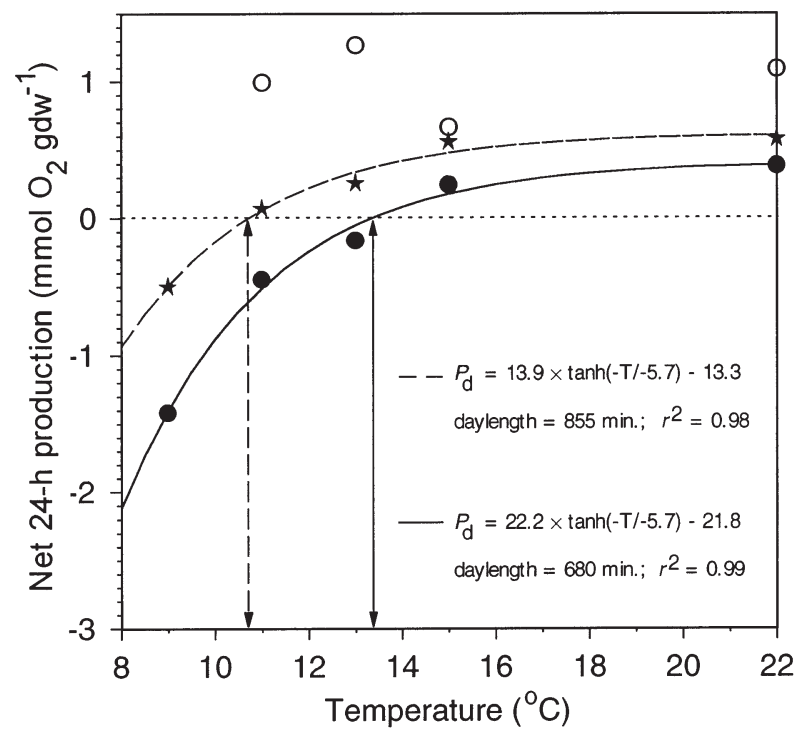

Fig. 4. Caulerpa taxifolia. Estimated net $24 \mathrm{~h}$ production by Caulerpa taxifolia samples as a function of treatment temperature, during exposure to cold water $(\bullet, \star$; daylengths as shown) and after re-acclimation to $22^{\circ} \mathrm{C}(\mathrm{O})$ 

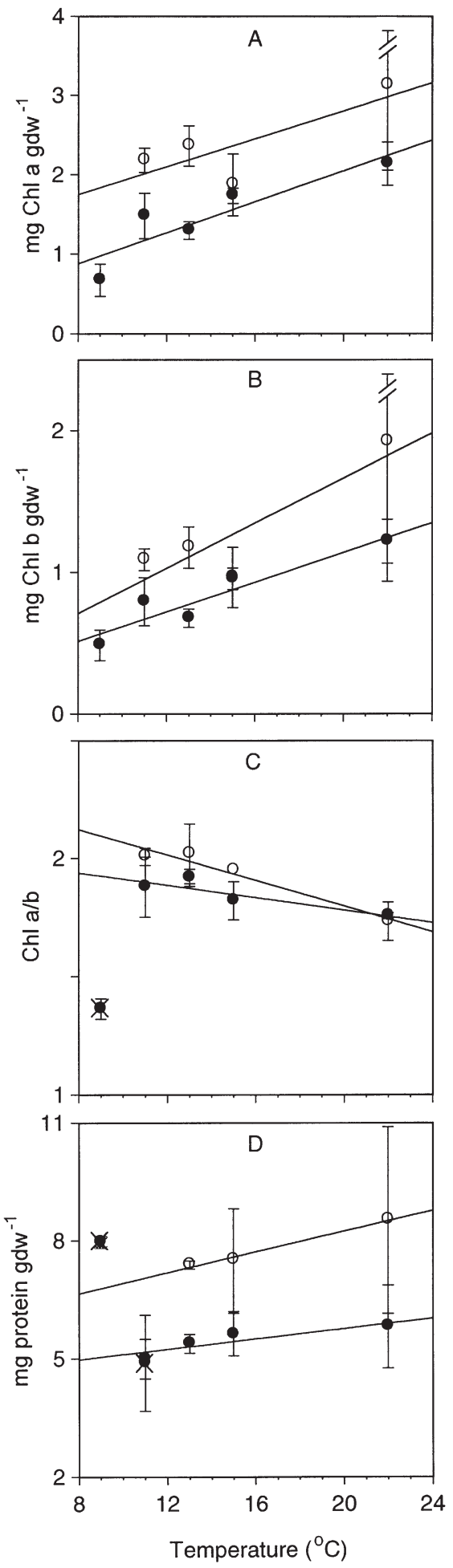

Fig. 5. Caulerpa taxifolia. Variation in (A) the concentration of chlorophyll $a_{i}$ (B) the concentration of chlorophyll $b_{\text {; }}(\mathrm{C})$ the ratio of chl $a$ to $\mathrm{chl} b$; and (D) the tissue protein content of samples during exposure to cold water $(\bullet)$ and after re-acclimation to $22^{\circ} \mathrm{C}(\mathrm{O})$. Regression lines indicate significant relationships $(\mathrm{p}<0.05)$; lines in $(\mathrm{C})$ and $(\mathrm{D})$ indicate significant relationships after removal of struck-through $(\times)$ data points; error bars are $95 \%$ confidence intervals content and treatment temperature (Fig. 5D). It therefore appears that samples may be incapable of regulating tissue composition at temperatures of 9 to $11^{\circ} \mathrm{C}$.

\section{After re-acclimation}

After samples formerly exposed to temperatures of 11,13 and $15^{\circ} \mathrm{C}$ had been brought back to the control temperature of $22^{\circ} \mathrm{C}$ and maintained for $2 \mathrm{wk}$ their photosynthetic and respiratory parameters were indistinguishable from those of the controls (Tukey-Kramer all pairs means comparisons at $\alpha=0.05)^{1}$. The $P_{\mathrm{m}}^{\mathrm{n}}$ of samples formerly exposed to $11^{\circ} \mathrm{C}$ increased by a factor of 5.7 , while that of samples exposed to $15^{\circ} \mathrm{C}$ increased by a factor of 2.3. The $P_{\mathrm{m}}^{\mathrm{n}}$ of control samples also increased ( $t$-test, $\mathrm{p}<0.05$ ) by a factor of 1.7 due to the seasonal increase in solar radiation which occurred between the end of cold treatment and the conclusion of experiments (130 to $186 \mu \mathrm{mol} \mathrm{m}^{-2} \mathrm{~s}^{-1}$; Fig. 3B).

The chl $a$ to $b$ ratio was inversely related to degree of previous cold exposure but the differences before and after treatment were minor (Fig. 5C).

Tissue protein concentrations after re-acclimation were significantly higher among all samples except those that had been incubated at $11^{\circ} \mathrm{C}$ and were directly proportionate to previous cold exposure (Fig. 5D). The relative tissue protein content of samples incubated at $11^{\circ} \mathrm{C}$ did not change significantly during reacclimation. Removal of data for $11^{\circ} \mathrm{C}$ samples indicated that the change in tissue protein content of other samples during re-acclimation to $22^{\circ} \mathrm{C}$ was due to the seasonal increase in solar radiation (i.e. significantly different $y$-intercepts, $\mathrm{p}<0.05$, but not slopes; Fig. 5D).

\section{DISCUSSION}

Data presented here indicate that the claim of a cold resistance threshold of $20^{\circ} \mathrm{C}$ for wild populations of Caulerpa taxifolia is incorrect. Survival of all samples at $11^{\circ} \mathrm{C}$ and death of all samples after exposure to $9^{\circ} \mathrm{C}$ suggest that Moreton Bay populations of C. taxifolia have a narrow cold tolerance threshold of between 9 and $11^{\circ} \mathrm{C}$, at least for periods of 4 to $6 \mathrm{wk}$. A more accurate estimate of the natural cold resistance of the species might therefore be $10^{\circ} \mathrm{C}$. Moreton Bay C. taxifolia thus exhibits similar cold resistance to Mediterranean populations $\left(10^{\circ} \mathrm{C}_{i}\right.$ Komatsu et al. 1997), confounding the idea that the cold tolerance capacity of the latter

\footnotetext{
${ }^{1}$ Tukey-Kramer all pairs means comparisons were used in preference to ANOVA because there are no suitable tests for variance heterogeneity when sample sizes are as small as 3
} 
results from aquarium-induced genetic modification or artificial selection.

Estimating $24 \mathrm{~h}$ net productivity $\left(P_{\mathrm{d}}\right)$ over the daylight period when measurements were made (early May) indicated that samples were photoautotrophically capable of maintaining their tissue biomass at temperatures $\geq 10.9^{\circ} \mathrm{C}$ (Fig. 4). Estimating $P_{\mathrm{d}}$ on the basis of a shorter photoperiod, in keeping with the period of the year when the sea is at its coldest near Monaco (February-March), indicated that a temperature of $\geq 13.5^{\circ} \mathrm{C}$ was needed for autotrophic maintenance of tissue biomass. Taking the more conservative latter estimate suggests that samples grown at 11 and $13^{\circ} \mathrm{C}$ exhibited insufficient photosynthesis to compensate for respiratory demand over $24 \mathrm{~h}$, assuming that short-term measurements of oxygen consumption were representative of $-R$ throughout the night. Thus, they either lost tissue biomass or acquired additional organic carbon from the substrata via their subterranean rhizoids (see Chisholm et al. 1996). Although we did not directly measure changes in biomass to avoid further stressing samples, we did observe that new fronds produced during cold treatment were smaller than the old fronds that degenerated, indicating a slow rate of overall tissue loss, typical of many organisms during winter. Such tissue loss may have been avoided had we allowed the samples to develop extensive rhizoid networks within the substratum prior to application of cold treatment. Regardless, data demonstrate that Moreton Bay Caulerpa taxifolia maintained sufficient biomass and photosynthetic activity over a period of $6 \mathrm{wk}$ at $11^{\circ} \mathrm{C}$ to regain its former growth potential once a favourable temperature regime was restored.

Discordantly high initial rates of photosynthesis at very low irradiance among 11 and $13^{\circ} \mathrm{C}$ samples following cold treatment did not appear to be manifest because of photoinhibition at higher irradiance. Data indicated no progressive trend toward lower rates of photosynthesis with increasing irradiance. Lower relative rates of photosynthesis at high irradiance may have been caused by redistribution of chloroplasts to protect against excess absorption of light or by destruction of photo-degradable rate-limiting components that had been synthesised in the dark.

Inverse relationships between both $I_{\mathrm{C}}$ and $-R$ and temperature contrast with the results of Gayol et al. (1995). Gayol et al. (1995), however, applied the reverse protocol to that used here. That is, they subjected low-temperature acclimated samples $\left(13\right.$ to $\left.18^{\circ} \mathrm{C}\right)$ to elevated temperatures during measurement of metabolic parameters and found that $I_{\mathrm{c}}$ and $-R$ typically increased. These 2 sets of results suggest that departures in either a positive or negative direction from a given acclimation temperature produce a rise in respi- ration rate consistent with a stress-induced increase in basal metabolism.

Exposure to $9^{\circ} \mathrm{C}$ water increased the ratio of protein to dry weight and decreased the ratio of chl $a$ to $b$ in samples. Increase in relative protein content was most likely due to decreased synthesis or increased consumption of non-essential metabolites (e.g. lipids and carbohydrates), consistent with a reduction in overall tissue biomass. Although cold treatment did not alter the protein content of samples maintained at $11^{\circ} \mathrm{C}$, the seasonal increase in irradiance which occurred during re-acclimation to $22^{\circ} \mathrm{C}$ did not cause a rise in tissue protein content consistent with other samples (Fig. 5D). Thus, while $11^{\circ} \mathrm{C}$ samples exhibited similar post-reacclimation rates of photosynthesis, they did not exhibit equivalent rates of protein synthesis. Possibly this was due to nitrogen limitation, caused by lack of rhizoid development within the substratum and reduced microbial nutrient cycling following low temperature treatment.
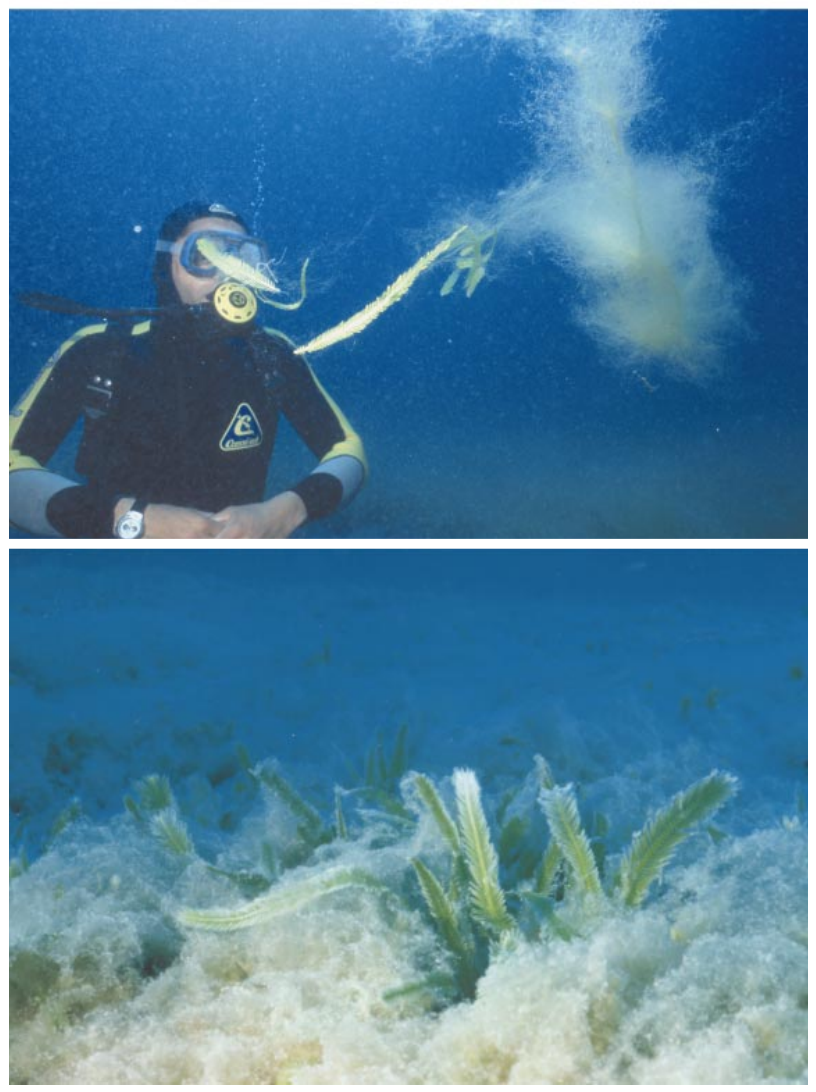

Fig. 6. Caulerpa taxifolia. Fragments trapped within almost neutrally buoyant cocoons of filamentous algae near Roquebrune-Cap Martin, SE France, in late summer 1997 (upper) after burial since early spring beneath a thick carpet of Ectocarpus sp. (lower). The upper photograph was taken just before a storm that carried thousands of these Caulerpafilamentous algal associations out to sea 


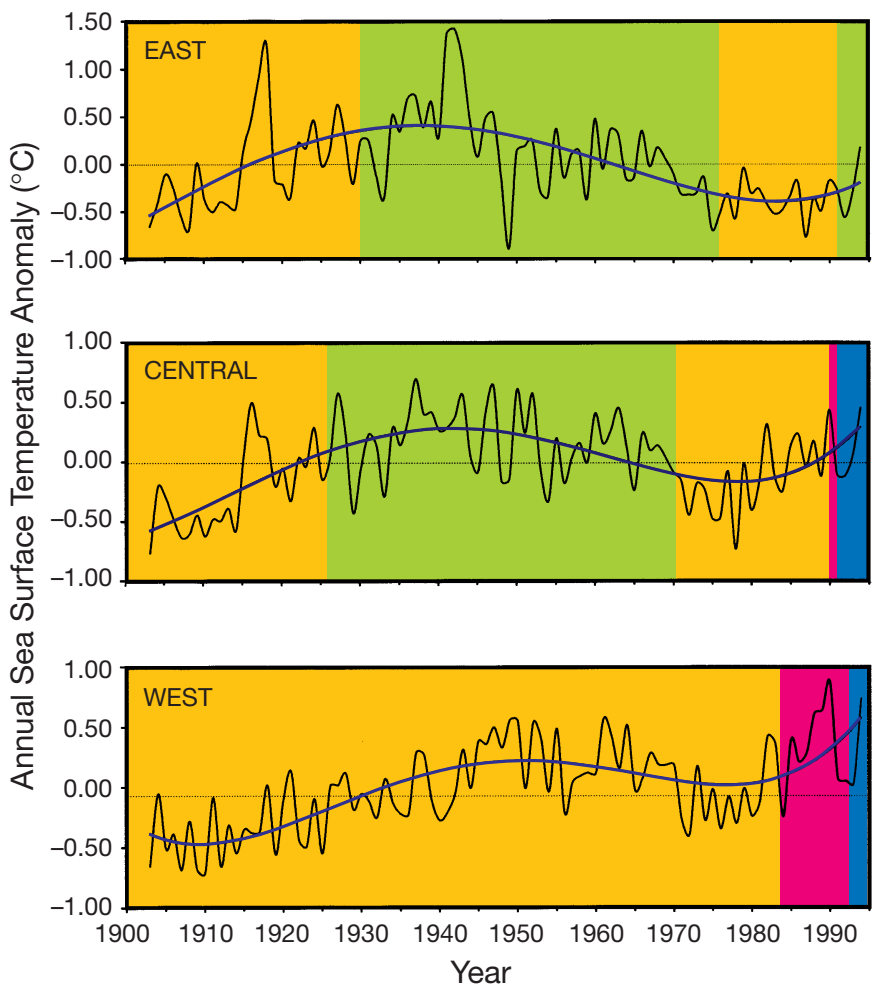

Fig. 7. Annual sea surface temperature anomalies in the Mediterranean Sea over the period 1903 to 1994 (GOSTAPlus SST dataset); data are fitted with 3rd order polynomials; orange shading indicates periods when there were no new reported occurrences of Caulerpa racemosa; green shading indicates periods when new occurrences of C. racemosa were reported in southern or eastern parts of the East Mediterranean; blue shading indicates first documented occurrences of C. racemosa in northern parts of the Central and West Mediterranean (see Doumenge 1995 for history); pink shading indicates first and subsequent documented occurrences of C. taxifolia in the Mediterranean (see Jaubert 1997 for history); note: where present, blue sectors overlie and thus conceal pink sectors that continue to 1994

Under cold conditions in the field, fragmentation and detachment of Caulerpa from the substratum must increase the chances of long-distance transport by ocean currents. Accompanying overgrowth by mucilaginous or filamentous algae, which has been observed in the sea near Monaco in spring and summer (Fig. 6), would further enhance the possibility of successful long-range dispersion by providing buoyancy and protection against excessive surface light. Why thermophilic species like $C$ racemosa remained localised for much of this century in the Levant Sea and then dispersed to the northwest Mediterranean over only the last 1 to 2 decades has not been explained (Chisholm et al. 1995).

Analysis of sea surface temperature records (GOSTAPlus) over the last century shows that new documented occurrences of Caulerpa racemosa in different regions of the Mediterranean, since its presumed arrival from the Red Sea via the Suez Canal (Hamel 1931, Rayss 1941, Aleem 1948, Rayss \& Edelstein 1960), tend to coincide with periods of especially warm water (Fig. 7). It further indicates that the species dispersed from regions experiencing abnormally cold water to regions experiencing abnormally warm water. Thus, a series of especially cold winters during the 1970s in the southeastern Mediterranean, where C. racemosa appears to be have been largely localised, preceded its dispersion to Turkey and Greece and then the western Mediterranean. Similarly, major radiation of C. taxifolia around the Mediterranean since its first known occurrence in 1984 (Meinesz \& Hesse 1991) appears to have coincided with a fall in seawater temperature between 1989 and 1991 (cf. Jaubert 1997, his Fig. 2 and references in text, with our Fig. 7).

In conclusion, it may be that cold water exposure stimulates range expansion of warm water Caulerpa species. Results presented here demonstrate that wild populations of $C$. taxifolia can exist well outside of the tropics. They weaken the basis of the claim that the strain of C. taxifolia existing in the Mediterranean has an aberrant genetic constitution and they bear testimony to the wide adaptive capabilities of a species that appears to infrequently undergo sexual reproduction (Benzie et al. 1997, 2000).

Acknowledgements. We thank Fany Seguin and Camille Lecat for technical assistance, Yves Berard for photography, and Janice M. Lough for kindly extracting sea surface temperature data. This work was funded by the Principality of Monaco and the Council of Europe.

\section{LITERATURE CITED}

Aleem AA (1948) The recent migration of Indo-Pacific algae from the Red Sea in the Mediterranean. New Phytol 47: 88-94

Benzie JAH, Price IR, Ballment E (1997) Population genetics and taxonomy of Caulerpa (Chlorophyta) from the Great Barrier Reef, Australia. J Phycol 33:491-504

Benzie JAH, Ballment E, Chisholm JRM, Jaubert JM (2000) Genetic variation in the green alga Caulerpa taxifolia. Aquat Bot 66:131-139

Boudouresque CF (1997) Dynamique des populations de Caulerpa taxifolia en Méditerranée, y compris les mécanismes de la compétition interspécifique. In: Dynamique d'espèces marine invasives: application à l'expansion de Caulerpa taxifolia en Méditerranée. Académie des Sciences, Paris. Tec \& Doc, Paris, p 145-162

Bradford MM (1976) A rapid and sensitive method for the quantitation of microgram quantities of protein utilizing the principle of protein dye binding. Anal Biochem 72: $248-254$

Caye G, Chambet P, Delahaye L, Meinesz A, Pietkiewicz D, Ryder K (1996) Differences entre Caulerpa taxifolia de Méditerranée et $C$. taxifolia des mers tropicales. In: Ribera MA, Ballesteros E, Boudouresque CF, Gomez A, Gravez 
V (eds) Second International Workshop on Caulerpa taxifolia. Publicacions Universitat Barcelona, Barcelona, p 171-176

Chisholm JRM, Jaubert JM (1997) Photoautotrophic metabolism of Caulerpa taxifolia (Chlorophyta) in the NW Mediterranean. Mar Ecol Prog Ser 153:113-123

Chisholm JRM, Jaubert JM, Giaccone G (1995) Caulerpa taxifolia in the northwest Mediterranean: introduced species or migrant from the Red Sea? CR Acad Sci Paris Ser III Sci Vie 318:1219-1226

Chisholm JRM, Dauga C, Ageron E, Grimont PAD, Jaubert JM (1996) 'Roots' in mixotrophic algae. Nature 381:382

Coppejans E, Prud'Homme van Reine WF (1992) Seaweed of the Snellius-II Expedition (E. Indonesia): the genus Caulerpa (Chlorophyta-Caulerpales). Bull Séanc Acad Roy Sci Outre-Mer Meded Zitt K Acad Overzeese Wet 37(1991-4):667-712

Cribb AB (1958) An ecological and taxonomic account of the marine algae of south-eastern Queensland. PhD thesis, University of Queensland

Darius HT, Tisserant B, Pagès G, Chisholm JRM, Jaubert J (1999) Phylogéographie de l'espèce Caulerpa taxifolia à l'aide de marqueurs moléculaires. Poster presentation3rd Workshop 'Evolution Biologique', Marseille, France, 10-11 June 1999. Observatoire Océanologique Européen, Centre Scientifique de Monaco, Monaco

Doumenge F (1995) Quelques réflexions sur les algues Caulerpes. Biol Mar Medit 2:613-633

Feldman J (1951) La flore marine de l'Afrique du Nord. CR Som Séances Soc Biogéogr 243:103-108

Gayol P, Falconetti C, Chisholm JRM, Jaubert JM (1995) Metabolic responses of low-temperature-acclimated Caulerpa taxifolia (Chlorophyta) to rapidly elevated temperature. Bot Mar 38:61-67

Hamel G (1931) Origine de la flore Méditerranée orientale. In: Laboratoire de Cryptogamie, Muséum National d'Histoire Naturelle, Paris (ed) Travaux cryptogamiques dédiés à L. Mangin. Muséum National d'Histoire, Paris, p 309-312

Harper JT, Garbary DJ (1997) Marine algae of northern Senegal: the flora and its biogeography. Bot Mar 40:129-183

Jaubert JM (1997) Sur l'expansion de Caulerpa taxifolia en Méditerranée. In: Dynamique d'espèces marine invasives: application à l'expansion de Caulerpa taxifolia en Méditerranée. Académie des Sciences, Paris, p 209-217

Jeffrey SW, Humphrey GF (1975) New spectrophotometric equations for determining chlorophylls $a, b, c_{1}$, and $c_{2}$ in higher plants, algae and natural phytoplankton. Biochem Physiol Pflanz 167:191-194

Editorial responsibility: Otto Kinne (Editor), Oldendorf/Luhe, Germany
Jousson O, Pawlowski J, Zaninetti L, Meinesz A, Boudouresque CF (1998) Molecular evidence for the aquarium origin of the green alga Caulerpa taxifolia introduced to the Mediterranean Sea. Mar Ecol Prog Ser 172:275-280

Komatsu T, Meinesz A, Buckles D (1997) Temperature and light resonses of the alga Caulerpa taxifolia introduced into the Mediterranean Sea. Mar Ecol Prog Ser 146: $145-153$

Lipkin Y (1973) Ecological distribution of Caulerpa in the Red Sea. J Mar Biol Assoc India 15:160-167

Meinesz A (1997) Origine et expansion de la forme méditerranéenne de Caulerpa taxifolia. In: Dynamique d'espèces marine invasives: application à l'expansion de Caulerpa taxifolia en Méditerranée. Académie des Sciences, Paris. Tec \& Doc, Paris, p 197-207

Meinesz A, Boudouresque CF (1996) Sur l'origine de Caulerpa taxifolia en Méditerranée. CR Acad Sci Paris Ser III Sci Vie 319:603-613

Meinesz A, Hesse B (1991) Introduction et invasion de l'algue tropicale Caulerpa taxifolia en Méditerranée nord-occidentale. Oceanol Acta 14:415-426

Meinesz A, Pietkiewicz D, Komatsu T, Caye G, Blachier J, Lemée R, Renoux-Meunier A (1994) In: Boudouresque CF, Meinesz A, Gravez V (eds) First International Workshop on Caulerpa taxifolia. GIS Posidonie Publ, Marseille, p 105-114

Meinesz A, Benichou L, Blachier J, Komatsu T, Lemée R, Molenaar H, Mari X (1995) Variations in the structure, morphology and biomass of Caulerpa taxifolia in the Mediterranean Sea. Bot Mar 38:499-508

Rayss T (1941) Sur les Caulerpes de la côte palestinienne. Palest J Bot Jer Ser 2:103-124

Rayss T, Edelstein T (1960) Deux Caulerpes nouvelles sur les côtes Méditerranéennes d'Israel. Rev Gén Bot 67:602-620

Sanderson JC, Thomas DP (1987) Subtidal macroalgal communities in the D'Entrecasteaux Channel, Tasmania. Aust J Ecol 12:41-51

Span A, Antolic B (1994) Pozor! Ovo je tropska alga Caulerpa taxifolia (Vahl) C. Agardh. Report of the Institut za Oceanografiju i Ribarstvo, Split

Taylor WR (1960) Marine algae of the eastern tropical and subtropical coasts of the Americas. Ann Arbor, University of Michigan

Taylor RW (1967) Species of Caulerpa (Chlorophyceae) collected on the International Indian Ocean Expedition. Blumea 15:45-53

Webb WL, Newton M, Starr D (1974) Carbon dioxide exchange of Alnus rubra: a mathematical model. Oecologia $17: 281-291$

Submitted: November 22, 1999; Accepted: April 27, 2000 Proofs received from author(s): June 16, 2000 